\section{UNIVERSITY \\ OF DEBRECEN}

FACULTY OF

HEALTH

NYÍREGYHÁZA

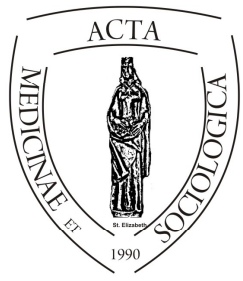

ACTA

MedSoc

VOLUME 5.

2014

\title{
Rendszerszemléletü és narratív megközelítések alkalmazása a terápiában
}

Esetismertetés

Bojti István

Pszichoterapeauta, belgyógyász orvos

\begin{abstract}
This paper deals with the therapy of a mother and her son. First we undertook a system-oriented approach; however, this process has stalled. The main reason this therapy stalled seemed to be the strong emotional commitment that the system approach was unable cope with, in this particular case. This difficulty was overcome by changing to constructivist narrative therapy. This paper introduces in detail the narratives of family members, the selection criteria for the narratives to be looked at, the externalization, and the ethical issues arising in the course of the therapy. We recognise the difference between the systemic family therapy approach and the narrative approach, within the framework of the Integral Theory, devised by Ken Wilber. According to his theory, the view of reality of the systemic approach, which is inherently striving for objectivity, and the constructivist therapeutic attitude, bearing in mind the client's subjective view of reality, are two alternative interpretations of the same reality. In this case the subjective approach proved more effective.
\end{abstract}

Keywords: family terapy, system oriented approach, narrative approach

DOI: $10.19055 / \mathrm{ams} .2014 .5 / 14-15 / 4$ 
Összefoglalás. Az alábbi tanulmányban egy anya és fia terápiáját mutatjuk be. Munkánk során kezdetben rendszerszemléletü megközelítést alkalmaztunk, ez a folyamat azonban elakadt. Úgy tünt, ennek oka a rendszerszemlélet által aktuálisan nem feldolgozható erős érzelmi elkötelezettség volt. Az elakadást a konstruktivista narratív terápiára váltással sikerült feloldani. Részletesen tárgyaljuk a családtagok narratíváit, a feldolgozandó narratívák kiválasztásának szempontjait, az externalizációt, a terápia során felmerülő etikai kérdéseket. A rendszerszemléletü és a narratív megközelítés különbségét a Ken Wilber nevéhez kötődő integrál elmélet keretei között értelmezzük. Eszerint a rendszerszemlélet eredendően objektivitásra törekvő valóságszemlélete és a kliensek szubjektív valóságát szem előtt tartó konstruktivista terápiás attitüd ugyanazon valóság két alternatív értelmezése. A bemutatott eset a szubjektív megközelítés prioritására hozott példát.

Kulcsszavak: családterápia, rendszerszemléletű megközelítés, narratív megközelítés

\section{Bevezetés}

A segítő munkában folyamatosan nehéz sorsú emberekkel dolgozunk. A sikerrel nem vagyunk elkényeztetve. Nem csoda, hogy a terápiás rendszereknek nagy keletje van. Egy olyan család terápiáját kívánom bemutatni, ahol két alapvetően különböző módszert, a rendszerszemléletü családterápiát, majd ennek eredménytelensége után a narratív terápiát alkalmaztam. Írásomban a két módszer összehasonlítására törekszem.

\section{Rendszerszemlélet}

A rendszerszemlélet nagyon népszerü a családterápiában, de nem csak itt, hanem az egész modern társadalom- és természettudományban is. Lépten-nyomon találkozunk ugyanis olyan jelenségekkel, ahol nagy számú elem kerül egymással sokrétü kölcsönhatásba, és jó lenne a folyamatot megérteni és befolyásolni. Ez a bonyolult feladat nem oldható meg a részek külön-külön leírása és ezek összegzése révén. A kísérlet eleve kilátástalan lenne.

A rendszerszemlélet a problémát úgy oldja fel, hogy a vizsgálni kívánt jelenséget egy egyéni tulajdonságokkal rendelkező önálló egésznek tekinti (László E. 2001). Ezt a konstrukciót nevezzük a továbbiakban rendszernek.

A rendszerszemléletű pszichoterápiák mintegy fél évszázados múltra tekintenek vissza, és több irányzatra oszlanak. Közös bennük a modernista alapállás: a családot és a patológiás tünetet a rendszerszemlélet fogalmaival értelmezik, és a terapeuta az ,objektív” külső szakértő. A terapeuta gondosan megtervezett intervenciókkal a rendszer paraméterein kezdeményez változtatást, mely visszahat a 
családtagok tapasztalatára, a tanulás lehetőségét teremti meg, és ez vezet a kívánt cél eléréséhez (Goldenberg és Goldenberg 2008).

A jelenségek rendszerszemléletü értelmezése a szokásos individuálistól eltérő nézőpontot kíván meg. A következőkben a rendszerek elemzéséhez szükséges néhány patamétert veszek sorra. Szem előtt tartom, hogy írásomban egy családterápiás esetről lesz szó, ezért az itt használatos fogalmakra fókuszálok, és egy családot tekintek a rendszernek (Goldenberg és Goldenberg 2008, Minuchin 1974).

A rendszerszemlélet nem az egyénre, hanem a kölcsönhatásra figyel. A kölcsönhatások felmérése informál a személyek kapcsolati hálójáról és a kapcsolatok minőségéről. A kölcsönhatások kommunikációt jelentenek,és ebben az értelemben számítsuk ide azt is, hogy a viselkedésnek, vagy néha akár a betegségnek is van kommunikációs jelentése. A kommunikáció megfigyelése az információk és a beavatkozási lehetőségek gazdag tárházát nyitja meg a terapeuta számára.

Alrendszerek. Egy családban lehet többféle alrendszer: szülők, gyermekek, házastársak, férfiak, nők, dominánsak, alárendeltek stb. Az alrendszerek fogalma akkor válik a terápiában jelentőssé, ha egy probléma értelmezésében célszerüek. Például egy gyermekeit szorosan kontrolláló szülő esetében megállapíthatjuk, hogy a gyermeki és a szülői alrendszer határai elmosottak, mert a szülő a gyermek feladatait részben átvállalja.

A határok. Ha rendszerekről, alrendszerekről beszélünk, akkor ebből következik, hogy kellenek határok. A családok esetében ez vonatkozhat térbeliségre (helyiségek funkciója, nyitott ajtók, együtt alvás stb.), az információáramlásra, a feladatmegosztásra, a jogokra, pénzügyekre stb. Lehetnek a határok merevek vagy ennek ellentéteként összemosottak, a középutat tiszta határoknak nevezzük. Ebben az esetben mindenki számára egyértelmü, hogy hol húzódnak a határok, és milyen szabályok szerint lehet ezeket megváltoztatni. A határok gondos elemzésével legtöbbször az egész családi patológia lenyomatát és intervenciós felületet kapunk.

A hierachia. A hierarchiában az van felül, akinek az akarata érvényesül. Tehát egy problémás személy, aki körül a család élete forog, ebben az értelemben a családi hierarchia csúcsán van. A pozíció változhat. Például egy agresszív részeg ember a hierarchia csúcsán van, másnap józanon, elviselve a családtagok szemrehányását a hierarchia legaljára kerül.

Szabályok. Nagyon fontos, részben kimondott, részben ki nem mondott a család életét meghatározó alapelvekről van itt szó, amelyek mélyen gyökereznek, nemegyszer több generációra nyúlnak vissza. Például: „A mi családunkban mindenki szorgalmasan dolgozik”. „Csak akkor tudok Neked segíteni, ha őszintén mindent elmondasz". A szabályok határozzák meg a rendszer eddig felsorolt jellemzőit is. 
Trianguláció. Amikor két személy a konfliktusát egymás között nem tudja megoldani, akkor előfordulhat, hogy az egyikőjük, vagy akár mindketten is egy további személyt a saját oldalukon bevonnak a konfliktusba. Nem csak egy családtagról lehet szó, a terapeuta is gyakran célja az ilyen törekvésnek. A háromszemélyes helyzetben kevesebb feszültség van, mint a diádikusban. A terápiás kapcsolatra nézve azonban súlyosan destruktív.

A rendszerszemléletủ családterápiában hasznosnak bizonyult néhány eredetileg a kibernetikában megalkotott fogalom. A családi rendszer homeosztázisa fenntartásában például szükséges a negatív visszacsatolás. Amikor két családtag a már számtalanszor lefolytatott vitába ismét belemegy és egyre indulatosabbá válnak, akkor a pozitív visszacsatolás eredményét látjuk. Mind a negatív, mind a pozitív visszacsatolás a lineáris okság modelljét követi. A családi folyamatokat a cirkuláris okság azonban legtöbbször pontosabban modellezi. Eszerint egy családtag tette a többi családtagra is hat, akik ezt a hatást saját újabb interakcióikban továbbadják, és a tovagyưrüző hatás eléri az első családtagot, és így tovább. Végül is ezen szemlélet jegyében nincs értelme az eseményeknek valamilyen kitüntetett kezdetét, azaz okát keresni, mert a tyúk vagy a tojás problémájához lyukadnánk ki. Az okok helyett a rendszer fenti jellemzőinek elemzése kínálkozik a beavatkozás lehetőségeként.

Végül az első és másodrendü változás fogalmát szeretném szóba hozni. A családtagok folyamatosan arra törekednek, hogy problémáikat megoldják. Az elért változásokat a rendszemlélet fent részletezett fogalmaival elemezhetjük. Az elért változást akkor tekintjük első rendünek, ha olyan kis mértéküek, hogy a fenti rendszer jellemzők változatlanok maradnak. Például egy szenvedélybeteg fiatalember megígéri, hogy többször nem fog inni, és az anyja eldugja a pincekulcsot. A másodrendű változás a rendszer fenti jellemzőinek a megváltozását jelenti. Például a fiatalember elköltözik otthonról és önálló életet kezd. A családi életciklusok közötti váltás eseteiben másodrendủ változásokat kell megvalósítani. Ennek elmaradásával sok terápiát igénylő konfliktus értelmezhető.

Szeretném kiemelni, hogy a rendszert leíró fenti paraméterek viszonylag objektívnek tekinthetők. Kevéssé a családtagok vagy a terapeuta szubjektív értékelésén alapulnak, inkább egy külső megfigyelő által megszerezhető információnak felelnek meg. Megismerésükhöz nem szükséges bonyolult értelmezésekbe bocsátkoznunk. (Wilber 2009) A pszichoterápiás gyakorlatban a rendszerszemléletnek ez az objektív jellege természetesen ennyire „tisztán” nem érvényesül, illetve a konstruktivizmus felé történő elmozdulásnak lehetünk a tanúi. Erre még később visszatérek. 


\section{Posztmodernitás.}

A filozófia posztmodern forradalma (Wilber 2009) elveti a modernitás korábbi koncepcióját, miszerint létezik egy objektív valóság, ami kívülálló nézőpontból, objektív tudományos módszerekkel kitartóan kutatva feltárható. A posztmodern felfogás szerint a megismerő is része a megfigyelt jelenségnek. Ezért a megismerés során szerzett információk a megismerő által mindig „,szennyezettek”, és ebből az következik, hogy a megfigyelötől függetlenül létező objektív valósággal nincs értelme számolni. Mint ahogyan ugyanaz a futballmeccs is egészen más aszerint, hogy a nyertes vagy vesztes csapat szurkolójaként figyeljük.

\section{A posztmodern korszakot a megismerés fejlődése kényszerítette ki.}

A fizika világából két példát említek meg: a kvantummechanika bizonytalansági relációját, miszerint egy részecske helye és sebessége egyidejüleg tetszőleges pontossággal nem határozható meg; a kozmológiában pedig arra a tételre utalok, ami szerint egy rendszer jelenlegi állapotához többféle megelőző történet tartozhat, amikhez különböző valószínűség rendelhető. Szó sincs egyik esetben sem egy objektív bizonyosságról.

A társadalom jelenségei hétköznapi tapasztalatainkhoz még közelebb állnak. Európában az elmúlt kétszáz évben a korábban a keresztény vallás által meghatározott homogén világkép széttöredezett. Ehelyett párhuzamosan létező egymásnak ellentmondó értelmezések sokasága tartja magát érvényesnek - és minden bizonnyal érvényesek is, attól függően, hogy kinek a szempontjából vizsgáljuk. Csak az individualizmus-kollektivizmus példáját említem meg, ahol az egymásnak ellentmondó igazságokra asszociálhatunk. Ugyanis az egyéni vagy a csoportérdek prioritásának dilemmájában valószínüleg mindenki tudna mindkét oldal mellett meggyőzően érvelni. A posztmodern szemlélet értelmezési keretet próbál adni egyre bonyolultabb világunknak.

\section{Konstruktivizmus.}

A konstruktivizmus illetve a szociális konstruktivizmus (Mahoney 2003) posztmodern szemléletü elméletek. Lényegük az, hogy a megfigyelő valóság élménye nem azonos magával a valósággal, hanem annak mentális konstrukciója. Azaz nem a terület maga, hanem egy térkép a területről. E konstrukció nyilván a konstruáló személyétől is függ, és ebben nyilvánul meg a posztmodern jelleg. A szociális konstruktivizmus a konstrukciók kultúra által befolyásolt és alapvetően nyelvi formát öltő jellegét hangsúlyozza (László 2005). Az ember tehát saját magáról, másokról és minden egyébről is azt gondolja, olyan értékeket követ, úgy viselkedik és érez, amilyen mentális konstrukciói vannak. A metafora alapján tehát a térkép a lényeg, nem a terület. A konstrukciók nyelvi karakterük révén megismerhetők, megbeszélhetők, megváltoztathatók. 
Saint-Exupéry és a szociális konstruktivizmus.

Az alábbi részlet A kis herceg című regényből származik. (Ford. Rónay György)

Ha azt mondjuk a fölnötteknek: "Láttam egy szép házat, rózsaszínü téglából épült, ablakában muskátli, tetején galambok..." - sehogy sem fogják tudni elképzelni ezt a házat. Azt kell mondani nekik: "Láttam egy százezer frankot érö házat." Erre aztán fölkiáltanak: "Ó, milyen szép!".

Ez a néhány sor jól illusztrálja azt a jelenséget, amikor a gyermek szocializációja még nem teljes. Még nem tanulta meg a társadalomtól, hogy egy ház konstrukciójának leglényegesebb tartalma a ház ára, és a galambok egyáltalán nem fontosak. A ,tanulatlan” gyermek konstrukciója más tartalmakból épült fel: szín, muskátli, galambok.

\section{Szociális konstruktivista pszichoterápiák.}

Az elmélet új terápiás szemlélet alapját teremtette meg. Vizsgáljuk meg, hogy mihez képest új ez a szemlélet. A pszichoanalízis, a viselkedésterápia, a kognitív pszichológia, a rendszerszemléletű terápiák, és még folytathatnánk a sort a többi modernista irányzattal, részletes modelleket dolgoztak ki a jelenségek értelmezésére a normálisról, a patológiáról, a terápiáról. Ezt az elméletet tekintik a valóság érvényes leírásának. Ebben a keretben helyezik el a klienst, és a rendelkezésre álló eszközökkel igyekeznek korrekciót elérni. A terapeuta itt szakértőként van jelen: az általa alkalmazott elméletnek megfelelően megpróbálja a kliens javulását támogatni.

A szociális konstruktivista terápiák újdonsága abban áll, hogy nem alkotnak meg olyan modellt, ami a kliens valóságát értelmezné. Hiszen ez a modell felfogásuk szerint úgyis torz lenne. Ehelyett a kliens által konstruált személyes valóságra figyelnek. Ebben a világban tájékozódnak, és keresnek olyan fogózókat, amik a kliens számára kielégítőbb konstrukciót eredményezhetnek. Ebben a rendszerben a terapeuta helyzete is más, mint a modernista irányzatok esetében. Itt ugyanis nem a külső szakértő jelleg dominál, hanem a terapeuta inkább résztvevő munkatárs. Közösen dolgoznak a konstrukciókon. A szociális konstrukciók nyelvi jellege miatt a terápiák nyelvezetét tudatosan a kívánt célnak megfelelően formálják (László J. 2005).

A továbbiakban két jelentős karriert befutó terápiás módszert emelek ki: a de Shazer nevével fémjelzett megoldásközpontú terápiát és a narratív terápiát.

A megoldásközpontú terápia (Berg 1991) az előzőekből következően nem fordít nagy figyelmet a probléma eredetére, sőt a részleteire sem. A terápiás aktivitás úgysem ilyen adatok felhasználásából indul ki. Ehelyett a terapeuta azt keresi, hogy a kliens emlékei között melyek azok, amikor a probléma nem állt fenn, vagy kevésbé állt fenn. Ezekben a sikeres időszakokban a kliens mit csinált másként, amit a jelenben is hasznosíthatna? Tipikus a „csoda” kérdés. Ha ma 
éjszaka csoda történne, és megoldódna a probléma, akkor mit csinálna holnap reggel másként? A kérdés célja az, hogy kiderüljön: milyen (feledésbe merült) tudás áll a kliens rendelkezésére a változáshoz.

A narratív terápia (White és Epston 1990) alapgondolata szerint a valóságról alkotott konstrukcióink formailag történetekből épülnek fel (László J. 2008). Ezek a történetek adnak jelentést a tapasztalatainknak. Fontos körülmény, hogy ezeket az életet meghatározó történeteket nem autonóm módon, hanem tekintélyszemélyek közremüködésével társadalmi nyomásra alkotjuk meg. A terápia lényege a meglévő problémás konstrukciók lebontása (dekonstrukció) és adaptívabb konstrukciók létrehozása. Ez a terápiás attitüd szükség esetén támogatja a közvélekedéssel szembeni fellépést, ezek helyébe az egyén saját maga választotta értékeit állítja. Érzékeny az egyén vagy a kisebbségek társadalom általi elnyomására, fontos morális alapállása az elnyomottak támogatása.

A narratív terápia a következö elvi lépésekben zajlik (Kecskeméti 2004):

- a domináns, problémához kapcsolódó, alternatívák nélküli történet megismerése, tudatosítása

- externalizálás -a személyiség és a probléma szétválasztása, a probléma „kihelyezése” nyelvi eszközök tudatos használatával

- dekonstruálás - a domináns történet további összefüggéseinek megértése

- kivételek keresése - az új történet rekonstrukciójához szükséges saját tapasztalatok tudatosítása

- rekonstrukció - új, sokszínü, alternatívákat tartalmazó történet létrehozása.

\section{Az eset ismertetése}

A következőkben a valós személyek azonosítására alkalmas adatokat megváltoztattam.

A család egy szabolcsi faluból származik. Anya még most is ott él, de a 24 éves lánya és a 21 éves fia már Budapesten dolgoznak. A szülők korán elváltak Apa italozása miatt. Apa másik faluba költözött, anyagilag a családot nem támogatta, a személyes kapcsolat is meggyengült, nem találkoznak minden évben. Anya egyedül maradt a két kisgyerekkel. Első munkahelyén, a helyi önkormányzatnál takarít jelenleg is, emellett a háztájiban gazdálkodik. Református vallásúak, rendszeresen járnak a templomba. Anya egész életét arra szánta, hogy a gyermekeiből tanult embert neveljen. Életének stratégiája, hogy ő pénzt nem tud a gyermekeinek adni, de diplomával már elboldogulhatnak az életben. Nem kímélte magát, éjjel-nappal dolgozott. De nemcsak saját magával, hanem a 
gyermekeivel is szigorú volt. Néha elcsattant az anyai pofon, és a gyerekek nem is mertek nem tanulni. Szerencsére okos, szorgalmas gyermekek voltak, hozták a jó jegyeket az iskolából. Harmadik osztályban Laci nagyon tehetségesnek bizonyult matematikából, mert a nővére házi feladatára tudott jó megoldást adni. Tehetséges matekosnak tartotta öt a környezete. A lány orvosit végzett, már férjhez ment, most rezidens. Lacival történt a baj. Gimnáziumba először Debrecenbe járt, kollégista volt. Gondjai voltak a tanulással, rossz jegyeket kapott. Félévkor a kettesért kellett felelnie több tantárgyból is. Az is kiderült, hogy Laci több időt tölt a szórakozással, mint kellene. Édesanyját a kollégiumi dáridók miatt hívták be az iskolába. Otthon nagy veszekedések voltak, ígérgetések, és a nyugtalanító helyzet miatt a második évfolyamra Lacit Nyíregyházára hozta át az édesanyja. Egy éven át itt is kollégista volt, de hasonló problémák miatt harmadik és negyedik évfolyamra az édesanyja kivette a kollégiumból és bejáró tanuló lett, mert így jobban ellenőrizhető volt a napirendje. A rossz helyzet azonban állandósult. Anya mindent megpróbált, hogy a fiát jobb belátásra bírja: fenyegetőzött, büntetett, jutalmazott, Lacit az apjához hasonlította, példaképnek állította a testvérét, de megoldásra nem jutott. Laci egyre inkább csak hallgatott, hazudozni kezdett, ami Anyát leginkább kiborította. Alig várta az érettségit ami közepes eredménnyel sikerült - és felvételt nyert Budapestre egy bölcsész szakra. Itt sem volt eredményes, hamar abbahagyta az egyetemre járást. Barátok, ivászatok, eladósodás következett. Amikor megbetegedett (baleset érte tisztázatlan körülmények között), vagy amikor az adóssága törlesztésére nem volt pénze, akkor testvéréhez, de leginkább anyjához fordult. Anya néha azt érezte, hogy megőrül a stressztől. Számtalanszor utazott el Budapestre, hogy személyesen kifizesse az albérleti díjat, kitakarítsa a szobáját, kifizesse az adósságát. Már akkor görcsbe rándult a gyomra, amikor a mobilján látta, hogy a fia hívja: mi van már megint? Amikor pedig nem hívta, akkor azt várta, hogy mikor fogja hívni. Mindemellett Laci dolgozott, munkahelye stabil volt, és keresetéből nagyon szerényen ugyan, de meg is tudott élni. Ebben az állapotban keresett meg Anya a rendelésemen.

\section{A terápia rendszerszemléletú időszaka.}

Az első ülésen Anya egyedül volt jelen. A problémájukat a rendszerszemlélet keretében az életciklusváltás problémájaként értelmeztem. Eszerint a serdülő gyermek nehézségekbe ütközik, de erre nem a szükséges változások sikeres megvalósításával reagálnak, hanem felemás módon a korábbi struktúra elemeit tartják életben. Fenntartják Laci alárendelt pozícióját: kéri az anyai támogatást, Anya ezt megadja és Laci visszaél vele. Ezek tapasztalatából kiindulva Anya fokozza a Laci feletti kontrollt, ami ellen egyfelől Laci lázad, ugyanakkor a következő percben kiprovokálja azt. Anarchikus szabályok, vitatott hierarchia érzékelhető. Nemhogy tisztulna az anya és fia között lévő határ, hanem minden 
korábbitól jobban összemosódott. Ennek megfelelő házi feladatot határoztunk el. Átgondoltuk, hogy milyen lépésekkel kellene Anyának Laci felé a saját határait megerősíteni. Ennek lényege első lépésben konkrétan az volt, hogy az anyagi támogatás kereteit Lacival beszélje meg, és tartsák magukat ehhez.

Nem akartam triangulálódni, ezért a következő ülésre elhívattam anyával Lacit is.

Ekkor ismerkedtem meg Lacival. Anya vádjait vita nélkül elfogadta. Önértékelése közel olyan alacsony szintű volt, mintha az édesanyjától hallottam volna. Ellenvetése abban állt, hogy a testvére sem olyan ragyogó ember, mint Anya gondolja, ö is megenged magának hajmeresztő dolgokat, csak vele szemben elnézőbbek. Másrészt neheztelt azért, amiért őt olyan okosnak kiáltották ki általános iskolában, nem is volt okos, mindig nagy stresszt jelentett neki megfelelni ennek az elvárásnak. Anya nagyon szigorúan büntette már a négyes osztályzatot is, állandóan félt töle emiatt.

Anya házi feladata erre az ülésre az volt, hogy dolgozzák ki Laci anyagi támogatásának szabályait. E tekintetben szinte semmilyen elörelépés sem történt, és erre számos magyarázattal szolgáltak.

A problémát immár Laci személyes részvételével értelmeztük. Lényegét tekintve a rendszerszemlélet keretei között maradtunk, és a továbblépést is ez határozta meg. Főbb elemei a következők voltak: gyermekkorától mostanáig is szigorú értékrend, magas szintü elvárások, melyek nem feleltek meg Laci igényeinek, illetve képességeinek. A családi kereteket középiskolás korában elhagyta, de jövőképe bizonytalan volt, a kortárs hatások érvényesültek. A felnőtt életének a feltételeit még egyelöre nem sikerült kialakítani. Ezzel kapcsolatos, hogy anyától még mindig függő helyzetben van. Megvizsgáltuk, hogy Lacinak konkrétan milyen lépéseket kell tennie az önálló élete stabilizálása felé és ezzel párhuzamosan Anyával a határok tisztázásában. Összegyüjtöttük azokat a tényeket, amik Laci erejét bizonyítják, és optimista, tevékeny hangulatban ért véget az ülés.

A harmadik ülésre Anya egyedül jött, mert Laci a munkahelyéről nem tudott elszabadulni időben. Néhány átmeneti kedvező tapasztalatot teljesen beárnyékolt az a tény, hogy Lacival 2 napig nem tudott beszélni, és biztos, hogy a rossz társaságában volt és hazudott. Pénzt kért ismét, és ő nem tudott nem adni, mert Laci érzelmileg megzsarolta. Érzi, hogy ilyen érzelmi nyomásnak később sem fog tudni ellenállni, hiszen Lacit ő szülte, és egy szülőnek mindig oda kell állnia a gyermeke mellé, akkor is, ha belepusztul.

Úgy éreztem, hogy nincs jogom ezt az érzést megkérdőjelezni. 


\section{A terápia narratív időszaka.}

A terápia ekkor fordulóponthoz érkezett. Részben azért, mert a rendszerszemléletü értelmezés és az intervenciók láthatóan nem hoztak eredményt, a másodrendű változás elmaradt. Másrészt Laci kimaradása reális veszéllyé vált. Laci és Anya párhuzamosan folyó narratív szemléletű egyéni terápiája mellett döntöttem. A módszerrel kapcsolatos személyes szimpátiám mellett több érv is erősítette a döntésemet:

1. Mindketten könnyen azonosítható elnyomó narratívák szerint értelmezték életük eseményeit.

2. Lacinak nagyon fontos lenne a családja által meghatározott, ránézve idegen és elnyomó narratívát személyesen konstruált másikra cserélnie

3. Laci jelenlegi alacsony motiváltsági szintjét a problémákat kívülre helyező, „felszabadító” hangulatú narratív terápia valószínüleg megerősítené

4. Tekintettel arra, hogy feladatuk kettejük egymásról leválása, a különkülön egyéni terápia ebből a szempontból valószínüleg előnyös lesz.

\section{Anya narratívái.}

Mint általában, Anyának is számos, a konfliktussal kapcsolatos narratívája volt. Felsorolok néhányat.

1. Általában lehet kölcsönt felvenni, de csak nagyon fontos dolgokra. Léhaságra nem lehet pénzt felvenni. Laci ezt megtette, ezért nem komoly ember.

2. A családban a bajok megoldásához elsősorban őszintének kell lenni egymáshoz. Bármi történik, együtt biztosan jobb megoldásokat lehet kitalálni - feltéve, ha öszinték vagyunk egymáshoz.

3. A mai világban a boldoguláshoz vagy sok pénz, vagy egy jó diploma kell. A mi családunk szegény, én nem tudok pénzt adni. Ezért tettem meg mindent, hogy kitaníttassam őket, de Laci nem tette hozzá a magáét, és most kallódik, az élete egy küszködés lesz.

4. Az én életem főmüve ez a két gyerek, az ő boldogságuk. Ha nekik bajuk van, az nekem rosszabb, mint nekik. Az örömük az én örömöm is.

5. Amikor a családban valakinek baja van, akkor segíteni kell ôt mindenáron, hiszen csak egymásra számíthatunk. Laci az elzüllés felé halad, tehát mindent meg kell tennem érte. 
Mielőtt a narratívákkal elkezdenénk a munkát, érdemes alaposan átgondolni a fenti listát, hogy kiválasszuk, melyikkel célszerü dolgozni.

1. Léhaság céljára kölcsönt felvenni. Ez egy olyan gondolat, amit én is vallok, nem tartanám érdemesnek dekonstruálni. A mégis ilyen kölcsönt felvevő ember sommás, végleges elítélése nyilván vitatható, a változásba vetett hit, a megbocsátás kérdéséhez vezet el. Laci és Anya viszonyában az utóbbi releváns kérdés, de nem érzem most a legfontosabbnak.

2. Öszinteség. Ez az elvárás sok konfliktust és kevés eredményt hoz Anya és Laci kapcsolatába. Sok ellenérvet lehetne a feldolgozás során találni, azonban mégsem kívánok vele foglalkozni, mert jelenleg marginális jelentőségü.

3. A jó diploma felemel. A szorgalmas, feltörekvő családok körében különösen gyakran központi jelentőségü narratíva. A sikertelenségét az élet kudarcának minősíteni beszükült értelmezésre utal. A családunk esetében ez tünik az egyik feldolgozandó narratívának.

4. Életem fóműve. Társadalmunkban főleg a hagyományos értékrendü családokban ez az uralkodó diskurzus része. Érvényes ez Anya esetében is. Házasságának megromlása óta, tehát két évtizede életét ez az elv vezérli. Bár ezen narratívának több alternatívája is érvényes lehetne, mély beágyazottsága miatt egyelőre nem kívánok ezzel foglalkozni. Később, a terápia előrehaladása lehet, hogy meghozza ennek a feltételeit is.

5. Családi támogatás. Ez a 4. ponthoz hasonlóan nagyon mélyen beágyazott narratíva, valószínúleg minden emberi kultúrában. Láthatóan Laci családjában is így van. Ennek ellenére ezt a narratívát nem kívánom érintetlenül hagyni, mint az ,életem fömüvét”, hiszen Laci felelőtlen viselkedése, anyjának manipulálása miatt nem lehet őt a felelősség alól tovább felmenteni.

A feltárt narratívák elemzése alapján végül a 3. és 5. számú, ,jó diploma” és „családi támogatás” látszik olyannak, amelyeket a várható nyereség és ellenállás mérlegelése után elsőként dekonstruálni érdemes.

\section{A ,jó diploma" narratíva feldolgozása.}

A narratívák dekonstrukciója első lépésben hagyományosan az externalizálással kezdődik. Ennek során a kliens által átélt, beazonosított probléma illetve tünet külön elnevezést kap, ezáltal a probléma, illetve a tünet külön entitást nyer. Ily módon elkülönül a klienstől, mintegy „,kívülre kerül”, azaz externalizálódik. Ez nemcsak megkönnyebbüléssel és a gyógyulás reményének megmutatkozásával jár, hanem az externalizált problémáról való gondolkozást is új módon teszi lehetővé. Fogunk az externalizálással még találkozni, azonban ennél a pontnál az 
externalizálástól kivézelesen eltekintettem. Externalizálni ugyanis azt a problémát kell, ami a kliensnek elég nagy szenvedést okoz, érzelmileg nagyon megérinti. Meg akar tőle szabadulni. Anya esetében a jó diploma feltétlen szükségessége kérdésében nem éreztem nagyon erős érzelmi elköteleződést, nem okozott már neki nagy szenvedést a diploma hiánya. Ehelyett az alternatívákra nagyobb nyitottságot észleltem. Valószínűleg már elindult az a folyamat, aminek a végére elfogadja Laci képzettségét. A dekonstrukció és az új narratíva rekonstrukciója a következő kérdések mentén történt: Milyen tapasztalatok támasztják alá, hogy a diplomás emberek gazdagabbak, jobb az életük, boldogabbak? Honnan származik erről az információja? Kiket ismer ebből a körből? Mi a különbség a falusi és a városi lakók között e tekintetben? Milyen kivételeket ismer: boldogtalan diplomást és boldog diploma nélkülit? Mit lehet tenni egy nem diplomásnak az élete boldogságáért? Ö mit tett a sajátjáért? Laci mit tett a sajátjáért? Hogy látja, most min dolgozik Laci a boldogsága érdekében? Mi a szülö felelőssége a gyermeke boldogságáért? Az ő szülei és ő, mint gyermek hogy volt ezzel? Ö mit várt el a szüleitől?

A kiindulási narratíva lényege az volt, hogy Laci csak kallódik, az élete egy küszködés lesz. Az ehelyett konstruált új narratíva Lacit küzdőképesnek látja, aki dolgozik a saját sorsának jobbításáért.

\section{A „ családi támogatás” narratíva feldolgozása.}

Anya súlyos szorongást élt át akkor, amikor Laci bajban volt. Hiába tudta, hogy lyukas hordóba tölti a bort, mégis mindig meghozta a kívánt áldozatot a fiáért, hogy kimentse szorult helyzetéből. A terápia első időszakában ennek már magam is tanúja voltam. Úgy érezte, hogy képtelen ellenállni egy érzésnek, miszerint segítenie kell. Logikailag értette, hogy nem jut vele előre, de az érzelmei csak ezt az egy viselkedést engedélyezték számára. Nem volt döntési helyzetben. Ezt a jól körülírható erős érzést externalizáltuk. Aggódásnak nevezte el. Aggódás tehát az a rész, amelyik rákényszeríti őt Laci feltétel nélküli támogatására. Aggódás dekonstrukciója két fő irányban haladt. Egyrészt magát a narratíva tartalmát dekonstruáltuk. Ennek lényege volt, hogy Aggódás Lacinak rövid távon ugyan használ, de hosszú távon árt. Megfosztja Lacit attól a lehetőségtől, hogy a saját kárán tanuljon. Másrészt Aggódás hatalmi hátterét is szóba hoztuk. Aggódással Anya nagyon mélyen azonosult, és egyáltalán nem gondolkodott azon, hogy milyen külső erők hatására alakult ki, és milyen hatalom segíti Aggódás erejét. Aggódás részben a generációkon átívelő minta megjelenése, másrészt nem hanyagolható el a tágabb család, az ismerősök Aggódást támogató föleg vélt, de részben minden bizonnyal valós attitüdje sem. Mit tegyünk, ha egy régi szabály a mi megváltozott körülményeink mellett akar érvényesülni? Mit 
van jogunk a hagyományokon változtatni? Mit kezdünk a felelősséggel, ha eszköztelenek vagyunk? Hogyan oszlik meg a felelősség Laci és Anya között? Anyával összesen háromszor találkoztam két hónapon keresztül a terápia narratív időszakában. Megtanulta a fia zsarolását elutasítani. Laci ezért először nagyon megharagudott rá, de egy héttel később felhívta, és megköszönte.

\section{Laci narratívája.}

Laci története megvalósulatlan reményekröl, kudarckerülésröl, a családja felé méltatlan viselkedéséről, zárt, azaz alternatívák nélküli depressziós jövőképről szólt. Nem tartalmazta az aktív változtatás lehetőségét. Ez a narratíva mindent elborított, mindenütt jelen volt, és csak ez volt jelen. Első lépésben e domináns narratíva kizárólagos létezését kérdőjeleztük meg. Könnyen kiderült, hogy nem csak a gyermekkorában, de már felnőttként is sikeresen küzdött meg nehézségekkel, például helytáll a munkahelyén és van baráti köre. Miután az alternatív narratíváknak is felsejlett a lehetősége, lehetővé vált a domináns depresszív narratívát Laci énképétől magától elkülöníteni, azaz externalizálni. Jól adja vissza ennek lényegét Michael White klasszikussá vált mondata: „A probléma a probléma, és nem az ember".

- Az a benyomásom, - mondtam Lacinak - hogy az Ön lelkében van egy rész, amely állandóan a kudarcokra emlékezteti. És bármit szándékozik Ön tenni, azt duruzsolja a fülébe, hogy az Ön élete már úgyis el van rontva, semmi sem fog már sikerülni.

A probléma és az ember elválasztását nagyban segíti, hogy a probléma saját nevet, ezáltal az önálló létezés lehetőségét kapja meg. Aminek neve van, az létezik. Azt lehet értelmezni, arról lehet gondolkozni, beszélni, átalakítani, feldolgozni stb. Laci a domináns narratívájának a „rossz lelkiismeret” nevet adta.

A dekonstrukció részeként „rossz lelkiismeret” konkrét hatását kerestük meg az elmúlt évek néhány zürös eseményében. Például bizonyos feladatokat el sem kezdett, mert eleve nem bízott magában. Magától adódott, hogy ezután a munkában történő helytállás mögött lévő belső küzdelmeit (korai felkelés, kevés fizetés megbecsülése stb.) is a „rossz lelkiismeret” és egyéb én-részek közötti egyezkedés keretében értelmezzük.

Külön figyelmet szenteltünk annak, hogy milyen külső erők hatására alakult ki „rossz lelkiismeret”. Ezt elsősorban édesanyjával hozta kapcsolatba. Tágítva a figyelem körét érthetö lett, hogy Anya is kulturálisan meghatározottan viselkedett. Apa elhagyta a feleségét és a gyermekeit, a családi emlékezet ezért apát felelőtlennek minősítette le. Anya egyedül maradt, és a sok generációs protestáns paraszti munkakultúrát és az apai szigort az egzisztenciális bizonytalanság erösítőjén keresztül adta át a gyermekeinek, és követelt tölük. Mindezt a tágabb család és a környezet elismerő tekintetének kíséretében. „Rossz lelkiismeretet” tehát Anya hozta létre társadalmi támogatással. Volt hozzá elég hatalma. De mi 
köze van ehhez Lacinak? Ez az Ö életterve, vagy az anyjáé? Miben azonos és miben más a kettő? Miben kell Anyához lojálisnak lennie és miben teheti meg, hogy ne legyen az?

„Rossz lelkiismeret” dekonstruálása és egy új narratíva rekonstruálása nem válik el egymástól, mert minden felismerés egyúttal az ellentéte felismerését is jelenti (Wilber 2000). Amint egy bizonytalan, elmosódott érzésben elkezdünk tudatosan részeket lehatárolni, azonnal adja magát a létrejött határ másik oldala, ami már az új narratíva konstrukciójába kerül beépítésre.

Így készítette el magának Laci az új narratíváját. Eszerint ő keresi a saját útját. Nehéz folyamat ez, sok megbotlás és felállás története, valamennyire el is maradt vele, de keményen küzd. Erős, most már tapasztalt is, és meg fogja tudni hozni a saját döntéseit. Ez egy nyitott, több alternatíva lehetőségét hordozó narratíva, amelynek Laci nem elszenvedője, hanem az aktivitása szembeötlő.

Fél évvel a terápia vége után Laci Budapesten szükös anyagi viszonyok között él, dolgozik, egyensúlyban van az élete. Havonta jár haza. Édesanyja a megállapodás szerint fizeti a rezsije egy részét, Laci ettől több pénzt nem kér. A saját életéről, a vitatott kérdésekről otthon nem beszél. Anya változatlanul aggódik, de úgy érzi, hogy távolságot tart a fiától. Ha ismét valami bajt csinálna, hagyná, hogy oldja meg saját maga. Békében élnek.

\section{Megbeszélés}

A klienseink mindig több releváns narratíváról számolnak be, és időnként szükség van arra, hogy kiválasszuk, ezekből melyikkel kívánunk először foglalkozni. Esetünkben ez anyánál igényelt megfontolást, Lacinál a választás nyilvánvaló volt. A narratíva kiválasztásának szempontjait az esetleírásban részletesen ismertettem, ezért itt csak egy szempontra, az etikaira kívánok kitérni.

A posztmodern, konstrukcionista alapszemléletü pszichoterápiák lényegéből fakad, hogy a kliensek által konstruált valóságot érvényesnek ismerik el. Sem a társadalom aktuális domináns diskurzusait, sem a terápiás rendszerek, sem pedig a terapeuta konstrukcióit nem helyezik a kliensé fölé. Sőt, a terapeuta és a kliens hangsúlyozottan egyenlő pozícióját hirdetik, illetve bátorítják a klienseket, hogy a domináns diskurzusokkal szemben éljenek kritikával, és találják meg sajátjaikat. A narratív irodalom az etikai kérdések körében többnyire azt hangsúlyozza, hogy a kisebbségekkel, a gyöngébbekkel, a betegekkel szemben a többség, az erősek és a segítők mértéktartóak, ezáltal etikusak legyenek (Kecskeméti 2004). A narratív terapeuták pedig legyenek tudatában, hogy helyzetüknél, tudásuknál fogva az erős oldalon vannak. Bátran támogassák a kisebbségben lévőket. 
Amellett, hogy a felsorolt érveket alapvetően elfogadom, muszáj szóvá tenni, hogy a pszichoterápiás gyakorlat szintjén, ahol egyénekkel, illetve egy-egy családdal foglalkozunk, a domináns diskurzussal szembeni bátor kiállás elve erösen individuális természetü. Tudjuk, hogy az individualizmus-kollektivizmus dimenziójában elfoglalt pozíciónk erősen függ a kultúránktól. A nyugati civilizáció az individualizmus felé lejt. A narratív terápia ezen belül is erősen individualistának számít.

\section{A kiegyensúlyozott gondolkozás érdekében érdemesnek tartom azonban a kollektivizmus értékeire is vetni egy pillantást.}

Azzal a nyilvánvaló ténnyel, hogy a hagyományok, az erkölcs, a vallás, vagy általában a kultúra milyen szükséges társadalomszervező funkciót tölt be szükségtelen foglalkozni. Ennek értékét még akkor sem vitathatjuk el, ha az egyénre nézve következményeik kétségtelenül gyakran represszívek. A konkrét terápiás gyakorlatban azonban nem kerülhetjük el a dilemmát. Esetünkben anya elkeseredett, és erkölcsileg leírta a fiát, mert az léhán élt. Lacinak pedig lelkifurdalása volt emiatt, és önmaga számára is kétes hitellel mentegetőzött. A léha életet a társadalom elítéli. Mit tegyen a terapeuta? Beáll a társadalmi kórusba, vagy relativizálni fogja a léhaságot, és segít a lelkifurdalást dekonstruálni? Mikor enyhítse a terapeuta a lelkifurdalást, és mikor nem? Ezekre a kérdésekre adott válaszok nyilván a terapeuta értékrendjéről és arról szólnak, hogy kívánja-e ezeket képviselni a terápiás térben. A bemutatott esetben mindenképpen a közvélekedés mellé kellett állnom. Részben könnyü volt, mert saját véleményemhez is ez állt közel, másrészt ellenkező esetben mindkét családtag előtt csorbult volna a hitelességem. A „bün” elismerésével viszont megnyílt az út a megbocsátás és a jóvátétel előtt. Az a tény, hogy a családtagok véleményét elfogadva a „léhaság” ellen foglaltam állást egyúttal lehetővé tette számomra azt is, hogy az ebböl levont túlzó következtetéseket (Laci az életét véglegesen elrontotta) hitelesen megkérdőjelezzem.

A jelen esettanulmány egyik legfontosabb kérdése kétségtelenül az, hogy miért volt eredménytelen a rendszerszemléletü terápia, mit nyújtott ehhez viszonyítva a narratív terápia, és mi a kapcsolat a két elméleti konstrukció között. A kérdés tárgyalását illő szerénységgel kezdem, elég nagy teret engedve az elméletek lényegéhez nem tartozó szubjektív tényezőnek.

A két módszer összehasonlításának jó keretét adja Ken Wilber Integrál elméletének a holonokat 4 irányból leíró modellje (Wilber 2007). A holon fogalmát elöször Koestler használta (Koestler 1967), jelentése részegész. Azaz egy olyan kategória, mely részekből áll, de önmaga is része egy nagyobb egységnek. A továbbiakban tekintsük a tanulmányozandó holonnak anya és Laci két fós családját! 
Az Integrál elmélet szerint anya és Laci történetéről alapvetően két oldalról tudunk információt szerezni. Az egyik egy külső megfigyelő objektív nézőpontja, a másik pedig Anya és Laci szubjektív világának értelmezése. Mind a két oldalt további két részre lehet felosztani aszerint, hogy a figyelmünket csak a megfigyelt személyekre korlátozzuk, vagy ehelyett a megfigyelt személy környezetével való kölcsönhatásait, a kollektív viszonyokat vesszük figyelembe. Hagyományosan ezt a szemléletet a síkot négy negyedre osztó mátrixszal illusztráljuk (1. ábra), ahol a bal oldali mezők a szubjektív, a jobb oldaliak az objektív, a felsők az egyéni, az alsók a kollektív minőséget jelentik.

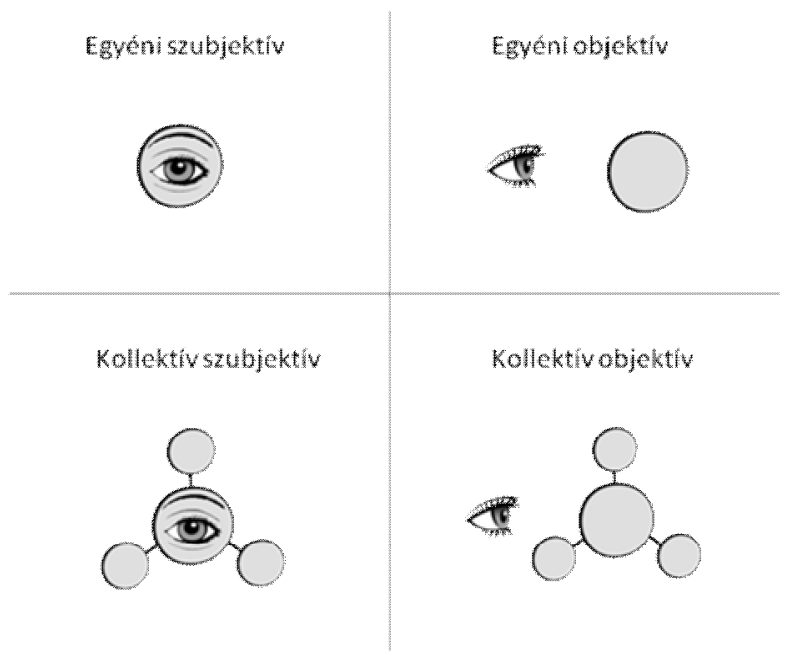

1 ábra.

A valóság négy oldala.

Négy egyenrangú megközelítésről van szó, minden megközelítés ugyanazokról a személyekről szól, más-más irányból. Az információszerzés módszerei azonban lényegesen különböznek.

A jobb oldal az empirista modern tudomány eszközeivel dolgozik. A mi pszichoterápiás esetünkben természetesen nem mikroszkópra vagy kérdőívek statisztikai feldolgozására gondolunk, hanem a jobb felső negyedbe tartozna például a tünetek leírásán alapuló BNO diagnózis. A kollektív, objektív (jobb oldali alsó negyed) területéhez tartozik a rendszerszemlélet. Az információk jelentős része természetesen a rendszerszemléletü terápiában is a kliensek elmondásából származik. A rendszer megismeréséhez azonban viszonylag objektív információk révén el lehet jutni, és maguk a megismert tények sem szorulnak bonyolult értelmezésre. Például a határok, a hierarchia, a szabályok, az 
életciklusváltás stb. mind-mind objektív, „,tudományos”, érzelem nélküli kategóriák. Egyértelműen definiált fogalmak, általában ugyanazt érti alatta mindenki. A mátrix bal oldalának, azaz Anya és Laci szubjektuma felőli megismerésnek viszont komoly módszertani nehézséggel kell megküzdenie. Valakinek a gondolatait, vágyait, szorongásait csak akkor ismerhetjük meg, ha ő közli velünk, és ezt helyesen értelmezzük. Ez a folyamat sok szürőn keresztül valósul meg, részleteit a hermeneutika tanulmányozza. (Bókay 2006) Az erőfeszítésért cserébe viszont a megismerő a másik személy szubjektumáról szerez tudást.

A narratív terápia szemléletét átgondolva azt látjuk, hogy a kliensek egyéni és kollektív szubjektív világában mozgunk. Maga a szociális konstruktivizmus lényege az objektív valóság helyett a szubjektív konstrukciók hangsúlyozása. Ebben a dimenzióban a lényegéből fakadó természetességgel dolgozunk Anya érzésével, hogy "Lacit ő szülte, és egy szülőnek mindig oda kell állnia a gyermeke mellé, akkor is, ha belepusztul". Amikor arról beszéltünk, hogy Laci „rossz lelkiismerete” nagyrészt anya és a helyi társadalom közvélekedése hatására alakult ki, akkor a mátrix bal alsó, azaz kollektív szubjektív mezőjében mozogtunk. A narratív terápia fókusza tehát a kliens érzésein volt.

Visszatérve a rendszerszemléletre, ebben a keretben a különbség még inkább látható. A rendszerszemléletű gondolkodásnál valóban nincs szó arról a nagyon bonyolult, a kliens és a terapeuta szubjektuma által egyaránt jelentéssel felruházott értelmezve megismerő folyamatról, mint a bal oldali negyedek esetében. Mindez azt is jelenti, hogy a szoros értelemben vett rendszerszemléletü gondolkodás mostohán viszonyul az érzelmekhez. A rendszerszemléletű terápiás térben természetesen ugyancsak nagyon intenzív érzelmeket élünk át, sírunk, nevetünk, katarzisban van részünk: de ez nem a tisztán vett rendszerszemlélet hozadéka, ez már attól több. Virginia Satir például ismert élményközpontú terápiájában a rendszerszemléletet Gestalttal és énpszichológiával ötvözte (Prochaska és Norcross 2011).

A rendszerszemléletü terápiák történetében fontos fejlemény, hogy Boscolo és Cecchin új poszt-milánói szemlélete szerint a családot és a terapeutákat egységes rendszernek tekintik, mivel a terapeuták aktív jelenlétükkel a családrendszernek elkerülhetetlenül részévé válnak. Miután a megfigyelt és a megfigyelő korábbi különállása ezáltal megszünik, egy lépés csak, és a terapeuták a szakértő mindent tudó pozícióját feladva a családdal közös konstrukciók alkotásában határozzák meg a terápia lényegét (Boscolo, Checcin, Hoffman, Penn 1987). Mindez a rendszerszemléletü és a konstruktivista terápiák ötvöződését, a szubjektív és objektív megértés integrálását jelenti.

A bemutatott esetben a modernista, rendszerszemléletü terápia elakadását az anya általam akkor megoldhatatlannak bizonyult érzelmi ellenállásával hoztam kapcsolatba. Ezt az elakadást egy a szubjektumra erősebben fókuszáló szemléletváltással sikerült megoldanom. A posztmodern, konstruktivista terápiás mód- 
szer esetünkben jobban kiszolgálta a hagyományait vesztett, olykor kaotikus viszonyok között élő család igényeit.

\section{Irodalomjegyzék:}

1. Berg, Insoo Kim (991): Konzultáció sokproblémás családokkal. Animula, Budapest.

2. Boscolo, Luigi; Checcin, Gianfranco; Hoffman Lynn; Pen, Peggy (1987): A milánói módszer. Animula, Budapest.

3. Bókay Antal (2006): Bevezetés az irodalomtudományba. Osiris, Budapest.

4. Goldenberg, Herbert és Goldenberg, Iren (2008): Áttekintés a családról Animula, Budapest.

5. Kecskeméti Molnár Mária (2004): Narratív terápia. Bemutató és ajánlás ÚjZélandból. Pszichoterápia 13. 6. 366-376.

6. Koestler, Arthur (1967): Szellem a gépben. (Ford. Makovecz Benjamin), Európa Kiadó, Budapest.

7. László Ervin (2001): A rendszerelmélet távlatai. Magyar Könyvklub, Budapest.

8. László János (2005): Történetek tudománya Új Mandátum Könyvkiadó, Budapest.

9. László János (2008): Narratív pszichológia. Pszichológia 28.4 301-317.

10. Mahoney, Michael J. (2003): Constructive Psychotherapy: Theory and Practice The Guilford Press, New York.

11. Minuchin, S. (1974): Családok és családterápia Animula, Budapest.

12. Prochaska, James O. és Norcross John. C. (2011): A pszichoterápia rendszerei. Animula, Budapest.

13. White, Michael és Epston, David (1990): Narrative Means to Therapeutic Ends. Norton \& Company, London.

14. Wilber, Ken (2000): Határok nélkül. Édesvíz Kiadó, Budapest.

15. Wilber, Ken (2009): A Működő Szellem rövid története Ursus Libris, Budapest.

16. Wilber, Ken (2007): Integrál szemlélet. Ursus Libris, Budapest.

dr. Bojti István: Pszichoterapeauta, belgyógyász orvos 